\title{
INTRA-AFRICA AGRICULTURAL TRADE: A SOUTH AFRICAN PERSPECTIVE
}

\author{
Y Daya, T Ranoto \& MA Letsoalo, Directorate: International Trade, Department of Agriculture, South \\ Africa
}

Purpose: The aim of this paper is to assess and provide an overview of the magnitude of current agricultural trade patterns between South Africa and the five leading regional economic communities (REC's) in Africa. This paper also seeks to examine some of the constraints limiting greater intra-African agricultural trade. This is done in order to better understand the role South Africa currently plays and could potentially play in promoting intra-Africa trade.

Design/Methodology/Approach: Trade flows between South Africa and the leading REC's are outlined and explained. Trade data and tariff data is sourced from available databases. Non-tariff barriers and other impediments to greater intraAfrican trade are examined with reference to available literature and discussions the authors have had with trade experts and policy makers.

Findings: South Africa is the most active country in intra-Africa agricultural trade. However, it is a relationship defined predominantly on exports to Africa with a low level of imports. South Africa exports a diverse range of value added products whilst imports remain concentrated in commodities. Significant imbalances in agricultural trade between South Africa and the respective REC's continue to persist. Regional trade arrangements have fostered greater trade but significant obstacles to greater trade remain.

Implications: African countries that do not invest in infrastructure and create a trade-enabling environment and diversify their production, limit their potential to the supply of one or two commodities thereby perpetuating the trend of huge trade imbalances in favour of South Africa.

Originality/Value: This work provides a platform for assessing trade relationships and examining impediments to greater trade. It is also relevant in guiding future research on priority markets in Africa as export destinations and import suppliers in light of increasing regional integration initiatives and governments commitment to African development.

Key words and phrases: Trade, intra-Africa, regional integration, constraints

\section{INTRODUCTION ${ }^{1}$}

The potential for regional integration to propel African growth and enhance Africa's ability to effectively participate in global trade is recognised by the African Union in its initiative to establish an African Economic Community. The African Union aims to promote the "economic, social and cultural development and integration of African economies in order to increase self-reliance and promote endogenous and self sustained development" (Abuja Treaty, 4). Enhanced intra-Africa trade holds potential for reducing the continents reliance on developed economies as engines of growth and also affords African producers and exporters the opportunity to develop the required products, capacities, competitive competencies, scale economies, skills and experience necessary for effective integration and participation in the global trading system. South Africa has a vital role in promoting greater intra-Africa trade. The relatively developed South African economy and agricultural sector compared to those of other African countries ideally places the country as a leader in promoting greater intra-Africa trade. The importance of Africa to South Africa is also underlined by the fact that the Southern African Development Community (SADC) is now the second largest export market for South African agricultural products.

This paper seeks to provide an overview and assess the magnitude of the current agricultural trade patterns between South Africa and the five leading regional economic communities (REC's) across the

\footnotetext{
1 This paper is based on research conducted as part of the Department of Agricultures broader intra-Africa research project. However, the views and opinions expressed herein are entirely those of the authors and do not reflect the views of the Department of Agriculture.
} 
continent. This paper also seeks to examine some of the constraints limiting greater intra-Africa agricultural trade. This is done in order to better understand the role of South Africa in intra-African agricultural trade. Section 2 of this paper outlines the methodology and data employed in the analysis. Section 3 includes a literature review providing a background to the study; the respective regional economic communities that form the basis of the analysis are also introduced. Section 3 also provides an overview of South Africa's bilateral agricultural trade relations with each of the selected regional economic communities in Africa. Section 4 examines the market access constraints prevailing between South Africa and the communities. Both tariff and non-tariff barriers to trade are dealt with in this section. Section 5 examines some of the implications of such constraints and suggests policy recommendations for addressing them. A concluding section is provided in section 6 .

\section{METHODOLOGY}

Trade data ${ }^{2}$ is sourced form the Global Trade Information Services World Trade Atlas (WTA) database. The WTA covers monthly, quarterly and annual trade data, in values and quantities of more than thirty countries with the rest of the world. South African data is sourced from the South African Revenue Service (SARS). The data in this analysis is sourced to the harmonised system (HS) classification and agricultural products are defined in terms of the World Trade Organisations (WTO) definition of agricultural products as contained in Annex 1 of the Agreement on Agriculture. The International Trade Centre's (ITC) Trade Map is also evaluated with reference to bilateral trade between South Africa and the respective REC's using specifically identified leading trade products. The Trade Map analysis is based on COMTRADE statistics accessed via software packages developed by the ITC (ITC, 2001). Trade flows are outlined and trade patterns explained. The leading products traded with each respective economic community are also outlined. The base year for the trade analysis in this study is 2005 .

Market access data is sourced from the ITC's Market Access Map database, the WTO trade statistics database and available literature. The Market Access Map database covers tariffs applied by over 170 countries to the products exported by 239 countries and territories with applied tariff data coming from the UN Tariff and Market Access database as well as directly from national sources. Bound tariff data comes from the Consolidated Tariff Schedule of the WTO and preferential tariff data comes directly from regional and bilateral trade agreements. Non-tariff barriers and other impediments to greater intra-African trade are examined with reference to available literature and discussions the authors have had with trade experts and policy makers.

\section{LITERATURE REVIEW}

The largely rural and underdeveloped nature of large parts of the African continent places agriculture at the forefront of any discussion on the economics of African development and growth. The agricultural sector directly accounts for over $60 \%$ of the total labour force; more than $20 \%$ of total merchandise exports; and approximately $20 \%$ of total GDP for Africa as a region (NEPAD, 2000:19). In addition to providing the primary source of foreign exchange earnings, agriculture plays the vital role of often providing the only source of livelihood for a large percentage of the continent's population. Any attempts at broad based development across the region therefore has to take cognizance of both the role agriculture needs to play and the contribution agriculture is likely to make to development initiatives. This realisation is reflected in the Common African Agricultural Development Programme (CAADP) initiated by the New Partnership for African Development (NEPAD) in terms of which, member states commit to increasing contributions to agricultural development initiatives.

\footnotetext{
${ }^{2}$ The authors accept that the reliability of trade statistics needs to be assessed with scepticism and pragmatism since perfect trade statistics do not exist. Omissions, underreporting, the erroneous classification of goods, values and quantities can all affect the reliability of statistics. However, the authors are of the view that although trade statistics cannot provide the precise information on traded values and quantities they do provide indication of orders of magnitude.
} 
The CAADP also recognises agricultural trade as one of the primary pillars upon which agricultural development needs to be based. African agricultural trade performance has declined significantly over the past three decades. Africa's share in global agricultural trade has declined from 8\% during the 1970 to 1980 period to approximately $3.4 \%$ in 2000 (UNECA, 2004). This dramatic decline is not confined to agriculture and is reflected across a range of industries with the continent's share in total global exports declining from $6 \%$ in 1980 to just over $2 \%$ in 2002 and its share in world imports from $4.6 \%$ in 1980 to $2.1 \%$ in 2002 (UNCTAD, 2003:1).

Dependence on commodity exports represents one of the primary reasons for Africa's poor trade performance. Commodity prices declined by an average of 5\% per annum during the 1980's and by 1990 commodity prices were $45 \%$ lower than the levels of 1980 . This trend of prolonged price declines as opposed to price fluctuations is characteristic of commodity markets, particularly in the absence of commodity agreements and/or adequate supply management. A narrow export product base and lack of alternative markets resulted in many commodity exporters exporting more in response to a lower price (technological advances and high yield varieties also contributed to increased output); this in turn drove prices further down reinforcing the downward cycle. Deteriorating terms of trade and the concomitant decline in revenue from commodity exports contributed greatly to the growth of foreign debt incurred by these nations resulting in insufficient resources being available for investment and savings that could have been used to diversify the production and export supply base. In many African countries this feature has become a structural feature of the economy and the losses associated with commodity dependence accounts for the poor economic performance and decline in living standards across many African economies and reflects what has come to be termed a "commodity trap" (South Centre, 1996).

External market conditions have also been a critical factor in the marginalisation of Africa in global trade. Tariff escalation and high tariff peaks in traditional export markets have contributed to Africa directing its resources to production in low value sectors rather than diversifying its export base from raw materials to intermediate or processed products. This is especially true in the agricultural sector. An additional consideration is domestic support. Even though many African countries enjoy preferential access to the markets of many developed countries, their ability to compete is undermined by the huge amounts of domestic support allocated to local farmers in those markets. African exporters also face a range of nontariff barriers such as sanitary and phytosanitary requirements and other technical barriers to trade. The above factors are compounded if one considers that Africa continues to be dominated by a legacy of trade with former colonial rulers. In addition, continued political instability, lack of human capital, inadequate infrastructure, underdeveloped governance structures and a range of other structural factors are often cited as reasons for explaining Africa's poor trade performance and relative inability to effectively participate in world trade.

The African Union has created regional economic communities (REC's) as an initial step to foster deeper integration and enhance intra-Africa trade. It is envisaged that enhancing intra-Africa trade, particularly in non-traditional commodities with high income elasticity and lower rates of protection, provides a valuable opportunity for enhancing production and trade diversification (Kousari, 2004). This, in turn, can facilitate the effective and sustainable integration and participation of African economies in global trade.

\section{Regional Economic Communities in Africa}

The regional economic communities employed in this analysis are those trade blocs envisaged as the 'pillars' for the African Economic Community by the African Union and include: the Economic Community of West African States (ECOWAS); the Economic Community of Central African States (ECCAS); the Southern African Development Community (SADC); the Common Market for Eastern and Southern Africa (COMESA); and the Arab Maghreb Union (AMU) ${ }^{3}$.

\footnotetext{
${ }^{3}$ The Arab Maghreb Union (AMU) does not participate in the African Economic Community because of opposition by Morocco.
} 
Table 1: Africa's leading regional economic groups

\begin{tabular}{|c|c|}
\hline $\begin{array}{l}\text { ECOWAS } \\
\text { Economic Community of West African States }\end{array}$ & $\begin{array}{l}\text { Benin; Burkina Faso; Cape Verde; Côte } \\
\text { d'Ivoire; Gambia; Ghana; Guinea; } \\
\text { Guinea-Bissau; Liberia; Mali; Niger; } \\
\text { Nigeria; Senegal; Sierra Leone; Togo. }\end{array}$ \\
\hline $\begin{array}{l}\text { ECCAS/CEEAC } \\
\text { Economic Community of Central African States }\end{array}$ & $\begin{array}{l}\text { Angola }^{\#} \text {; Burundi^; Cameroon; Central } \\
\text { African Republic; Chad; DRC } \text {; Congo; } \\
\text { Equatorial Guinea; Gabon; Rwanda^; } \\
\text { Săo Tomè and Principe. }\end{array}$ \\
\hline $\begin{array}{l}\text { SADC } \\
\text { Southern African Development Community }\end{array}$ & 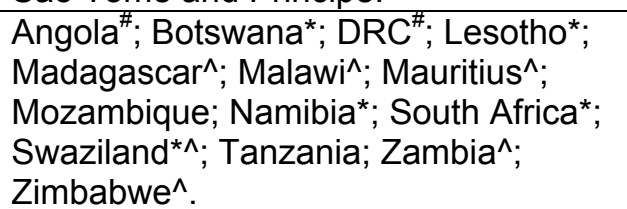 \\
\hline $\begin{array}{l}\text { COMESA } \\
\text { Common Market for Eastern and Southern Africa }\end{array}$ & 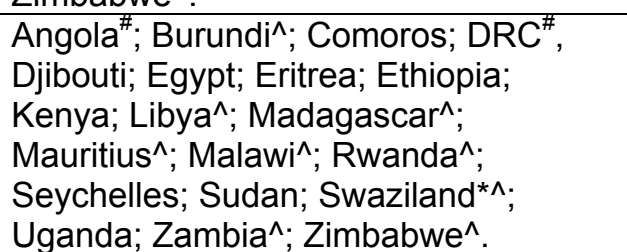 \\
\hline $\begin{array}{l}\text { AMU/UMA } \\
\text { Arab Maghreb Union }\end{array}$ & $\begin{array}{l}\text { Algeria; Libya^; Mauritania; Morocco; } \\
\text { Tunisia. }\end{array}$ \\
\hline
\end{tabular}

Source: CIA World Fact Book and IMF WEO Database.

* SACU members.

$\wedge$ overlapping memberships in at least two 'pillar' regional economic groups.

\# overlapping membership in at least three 'pillar' regional economic groups.

Table 1 outlines each community's respective members. The establishment of these regional economic communities is intended to facilitate the establishment of a continent-wide customs union by 2019 , an African Common Market by 2023, and a continent-wide economic and monetary union by 2028 (Abuja Treaty).

It should be noted that there are multiple regional communities with overlapping memberships. Several subgroups of tighter customs and monetary unions also exist within the respective regional economic communities, e.g. Southern African Customs Union (SACU) within SADC, Economic and Monetary Community of Central Africa (CEMAC) within ECCAS and the West African Economic and Monetary Union (UEMOA) within ECOWAS. For the purposes of this paper, only SACU ${ }^{4}$ members are specifically excluded from the analysis and, unless specifically stated, no further rationalisation of the respective memberships or overlapping memberships is undertaken. Therefore, with the exception of SACU members, each community is examined in respect of its entire membership as outlined in table 1. Excluding SACU member states, the economic communities that form the basis of this analysis comprise 48 African countries. The largest community both in terms of membership, total GDP and population is COMESA. Table 2 includes SACU data and contrasts the different communities in respect of population size, total GDP in current values, the role of agricultural trade in their respective trade profiles ${ }^{5}$, and the status of regional integration within the community.

\footnotetext{
${ }^{4}$ The Southern African Customs Union (SACU) is comprised of South Africa, Botswana, Lesotho, Namibia and Swaziland.

${ }^{5}$ Data is sourced from the World Trade Organizations trade statistics database and the World Bank. Data on agricultural trade as a percentage of total exports and imports is calculated as a simple average. Data on the agricultural trade profiles for the following countries was not available at the time of compiling this article: ECOWAS (Cape Verde, Guinea Bissau, Liberia and Togo); ECCAS (Chad, Democratic Republic of Congo and Equatorial Guinea); SADC (Democratic Republic of Congo); COMESA (Democratic Republic of Congo, Djibouti and Libya); AMU (Libya and Mauritania).
} 
Table 2: Comparison between economic communities 2004

\begin{tabular}{|c|c|c|c|c|c|c|}
\hline $\begin{array}{l}\text { Economic } \\
\text { Community }\end{array}$ & $\begin{array}{l}\frac{\text { Total }}{\text { Population }} \\
\text { (thousands, } \\
\underline{\text { 2004) }}\end{array}$ & $\begin{array}{l}\text { Total GDP } \\
\text { (million } \\
\text { current } \\
\text { US\$, 2004) }\end{array}$ & $\begin{array}{l}\text { Agriculture } \\
\text { (as \% of total } \\
\text { exports) }\end{array}$ & $\begin{array}{l}\text { Agriculture } \\
\text { (as \% of } \\
\text { total } \\
\text { imports) } \\
\end{array}$ & $\begin{array}{l}\text { Free trade } \\
\text { Area }\end{array}$ & $\begin{array}{l}\text { Customs } \\
\text { Union }\end{array}$ \\
\hline ECOWAS & $256,960,063$ & 133,728 & 40 & 24 & proposed & $\begin{array}{l}\text { proposed } \\
\text { for } 2007\end{array}$ \\
\hline ECCAS & $119,557,813$ & 64,439 & 38.4 & 22 & $\begin{array}{l}\text { proposed for } \\
2007\end{array}$ & $\begin{array}{l}\text { proposed } \\
\text { for } 2011\end{array}$ \\
\hline $\begin{array}{l}\text { SADC } \\
\text { (excluding SACU) }\end{array}$ & $177,884,472$ & 78,449 & 37 & 16 & $\begin{array}{l}\text { proposed for } \\
2008\end{array}$ & $\begin{array}{l}\text { proposed } \\
\text { for } 2010\end{array}$ \\
\hline $\begin{array}{l}\text { COMESA } \\
\text { (excluding SACU) }\end{array}$ & $380,927,644$ & 221,546 & 48 & 20 & progressing $^{6}$ & $\begin{array}{l}\text { proposed } \\
\text { for } 2008\end{array}$ \\
\hline AMU & $81,550,711$ & 193,364 & 10 & 16 & stalled & stalled \\
\hline SACU & $52,272,801$ & 230,681 & 19.4 & 15 & fully in force & $\begin{array}{l}\text { fully in } \\
\text { force }\end{array}$ \\
\hline
\end{tabular}

Source: Based on WTO, World Bank, and African Union data.

Each economic community is generally characterised by the presence of one or two large economies and/or populations that dominate the respective communities. These large economies are envisaged as acting as poles and drivers of growth in their respective regions. Within ECOWAS, Nigeria is the dominant economy accounting for almost $55 \%$ of the region's entire population and $54 \%$ of the communities' GDP. Ghana and Côte d'Ivoire are other significant contributors to the region's total population and GDP. Within ECCAS, the largest economy is that of Angola, which accounts for $31 \%$ of the region's total GDP but only $11.5 \%$ of the total population. The Democratic Republic of Congo accounts for almost $48 \%$ of the population but only $10 \%$ of total GDP. Cameroon is also an important regional economic power both in terms of GDP and population.

Excluding SACU countries, the largest economy in the SADC region is Angola, contributing $25 \%$ of the region's GDP. Zimbabwe contributes $23 \%$ to the region's GDP and ranks as the second largest economy. The Democratic Republic of Congo and Tanzania account for $31 \%$ and $20.5 \%$ of the region's total population. The dominant economy in COMESA is Egypt contributing almost $34 \%$ of the region's total GDP and $18 \%$ of the region's population. Other significant contributors to the region's total GDP include: Libya, Angola, Sudan, Zimbabwe and Kenya. Algeria and Morocco are the largest economies in the AMU both in terms of GDP and population. Algeria contributes almost $44 \%$ of the region's GDP and $40 \%$ of the region's population. Morocco contributes $26 \%$ to the region's total GDP and $37.5 \%$ of the region's population.

As table 2 indicates, even though SACU is a subgroup of SADC, it represents the largest economic region in Africa. This is largely due to the economy of South Africa that dominates SACU, accounting for $87 \%$ of the customs unions' population and $92 \%$ of its GDP. This underlines the importance of the South African economy not only to SACU or SADC, but also the entire continent.

\section{Agricultural Trade Flows}

The deregulation of the agricultural sector coupled with political changes in South Africa since 1994 has resulted in South Africa being integrated into the global economy. This has resulted in trade becoming an increasingly important component in the agricultural economy. Although the European Union remains South Africa's largest single export market, integration into the global economy has resulted in export

\footnotetext{
${ }^{6}$ Not yet participating: Uganda, Seychelles, Ethiopia, Eritrea, Angola, the Democratic Republic of Congo (in talks to join); Comoros and Libya (to join in 2006); Swaziland (on derogation until SACU permission obtained).
} 
markets being increasingly diversified into faster growing developing markets. Africa represents one such market accounting for approximately $24 \%$ of the export value of agricultural products and supplying almost $8 \%$ of South Africa's agricultural imports in 2005. Table 3 outlines and compares South Africa's agricultural trade profile across the various economic communities in Africa and highlights the significant imbalance in agricultural trade between South Africa and the respective regions. The fact that exports to Africa have grown faster than imports from Africa also indicates that this trend is not being reversed. Overcoming these imbalances remains a central challenge in fostering greater intra-Africa trade. It is evident from the table that, with the exception of ECCAS, exports to African regions have grown at a faster rate than exports to the rest of the world. SADC ranks as the largest agricultural export market in Africa making up almost $18 \%$ of the total export value and $75 \%$ of African export value. The fastest growing regions for exports are the $\mathrm{AMU}^{7}$ and ECOWAS.

Value addition, in response to globalisation challenges, changing consumer preferences, food safety considerations and technical conditions, has become a vital component of South Africa's agricultural exports. The diverse nature of the products exported into Africa reflects the fact that the composition of South African agricultural exports has shifted to processed products, which now make up in excess of $60 \%$ of the total export value (DoA, 2001). Table 4 provides a list of the leading product clusters exported to the respective regions. The significant ${ }^{8}$ markets within the respective regions are also listed in order of importance. As table 4 indicates, South Africa recorded significant exports to all region member states except: Burkina Faso and Guinea Bissau (ECOWAS) and the Central African Republic; Chad; and Sao Tome and Principe (ECCAS).

Table 3: Trade profile of South Africa with Africa

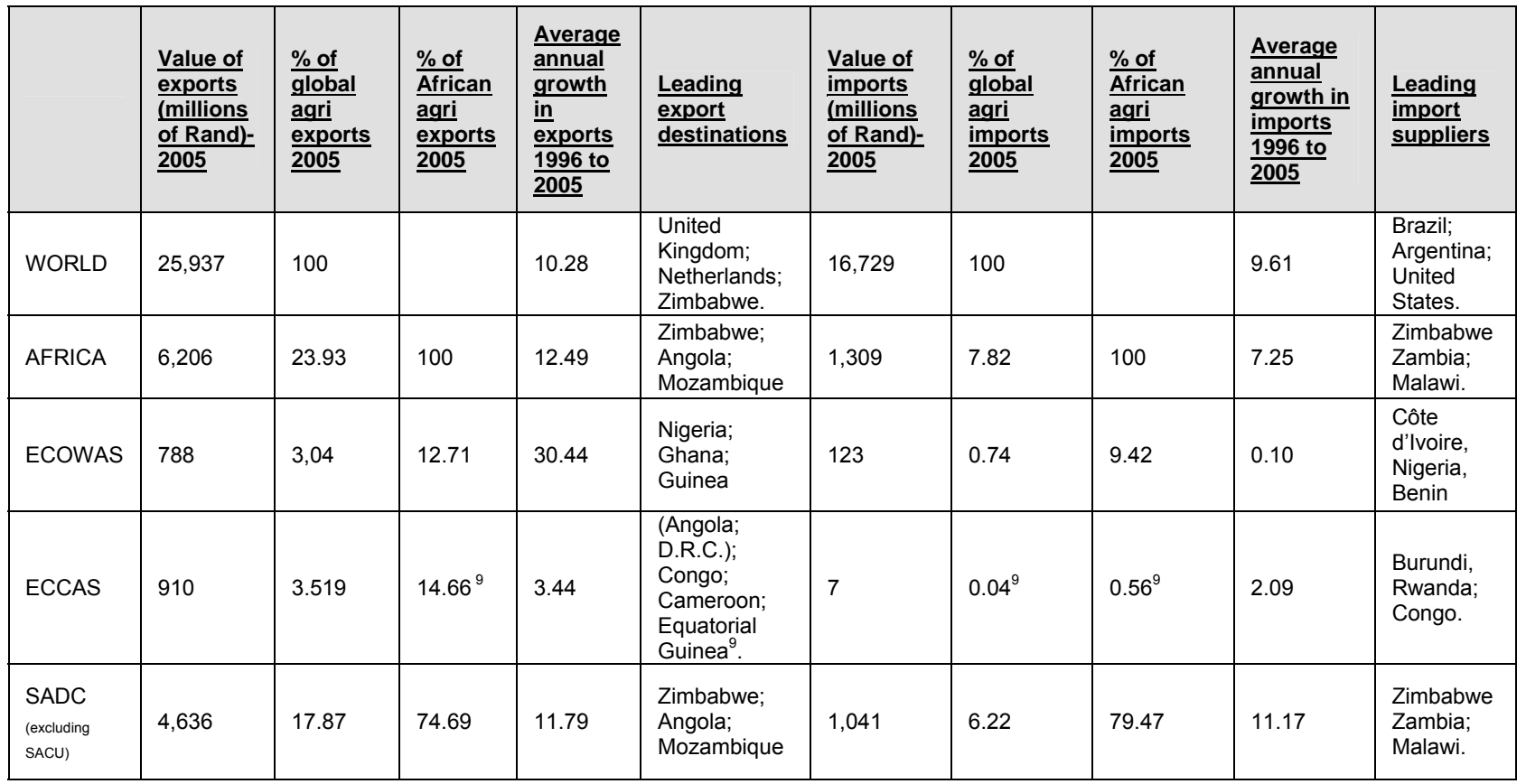

\footnotetext{
${ }^{7}$ It should be noted that the large growth in exports to AMU and imports from the AMU is recorded starting from a relatively low base.

${ }^{8}$ Significance of a market is determined on the basis of 2005 data. Exports to and imports from a market in excess of 1 million rand is the criteria used to determine if a market is significant.

9 Exports to Angola and the Democratic Republic of Congo excluded. If exports to Angola are excluded, exports to ECCAS only constitute $1.1 \%$ of global export value and $4.5 \%$ of African export value. If exports to the Democratic Republic of Congo are also excluded, ECCAS only accounts for $0.5 \%$ of total South African agricultural export value and $2.1 \%$ of African export value. Angola and the Democratic Republic of Congo import values were not isolated since no significant imports were recorded in 2005.
} 


\begin{tabular}{|c|c|c|c|c|c|c|c|c|c|c|}
\hline $\begin{array}{l}\text { COMESA } \\
\text { (excluding } \\
\text { SACU) }\end{array}$ & 4,401 & 16.9510 & $70.85^{10}$ & 13.48 & $\begin{array}{l}\text { Kenya; } \\
\text { Egypt; } \\
\text { Uganda }^{10}\end{array}$ & 1,057 & $6.32^{10}$ & $80.79^{10}$ & 9.98 & $\begin{array}{l}\text { Kenya; } \\
\text { Egypt; }^{10} \text { Uganda }^{10}\end{array}$ \\
\hline AMU & 59 & 0.22 & 0.95 & 89.41 & $\begin{array}{l}\text { Algeria; } \\
\text { Mauritania; } \\
\text { Morocco. }\end{array}$ & 19 & 0.11 & 1.44 & 29.52 & $\begin{array}{l}\text { Morocco; } \\
\text { Tunisia; } \\
\text { Algeria }\end{array}$ \\
\hline
\end{tabular}

As import suppliers, Africa's relative importance to the South African market remains low. Only $7.8 \%$ of total agricultural imports are sourced from African countries. SADC and COMESA rank as important import suppliers for South Africa, accounting for over $6 \%$ of South Africa's total agricultural imports and approximately $80 \%$ of South Africa's African agricultural imports. The AMU ${ }^{7}$ and SADC have recorded the highest level of growth of exports to South Africa. However, even though all regions have shown growth in exports to South Africa, Africa as a continent has recorded lower growth than the global average. In addition, as table 4 indicates, most agricultural imports from other African countries remain concentrated in commodities such as cotton (SADC and COMESA), tobacco (ECCAS), coffee, tea, mate and spice (SADC and COMESA), cocoa and cocoa preparations (ECOWAS) and oil seeds (SADC and COMESA).

\section{Table 4: Leading products traded and leading trade partners in Africa 2005}

\begin{tabular}{|c|c|c|c|c|}
\hline $\begin{array}{l}\text { Economic } \\
\text { Community }\end{array}$ & $\begin{array}{l}\text { South Africa's } \\
\text { leading export } \\
\text { products }\end{array}$ & $\begin{array}{l}\text { Exports }>1 \text { million } \\
\text { Rand in } 2005\end{array}$ & $\begin{array}{l}\text { South Africa's } \\
\text { leading import } \\
\text { products }\end{array}$ & $\begin{array}{l}\text { Imports > } 1 \text { million } \\
\text { Rands in } 2005\end{array}$ \\
\hline ECOWAS & $\begin{array}{l}\text { Sugars; } \\
\text { miscellaneous edible } \\
\text { preparations; tobacco; } \\
\text { beverages; cereals; } \\
\text { milling products and } \\
\text { edible fruits and nuts. }\end{array}$ & $\begin{array}{l}\text { Nigeria; Ghana; Guinea; } \\
\text { Mali; Benin; Côte } \\
\text { d'Ivoire; Sierra Leone; } \\
\text { Senegal; Togo; Liberia; } \\
\text { Gambia; Cape Verde } \\
\text { and Niger. }\end{array}$ & $\begin{array}{l}\text { Cocoa and cocoa } \\
\text { products and food } \\
\text { industry residue and } \\
\text { waste }\end{array}$ & $\begin{array}{l}\text { Côte d'Ivoire; Nigeria; } \\
\text { Benin and Ghana. }\end{array}$ \\
\hline ECCAS & $\begin{array}{l}\text { Sugars; tobacco; } \\
\text { beverages; } \\
\text { miscellaneous edible } \\
\text { preparations; cereals } \\
\text { and edible fruits and } \\
\text { nuts }\end{array}$ & $\begin{array}{l}\text { Angola; Democratic } \\
\text { Republic of Congo; } \\
\text { Congo; Cameroon; } \\
\text { Equatorial Guinea; } \\
\text { Gabon; Rwanda and } \\
\text { Burundi. }\end{array}$ & Tobacco & $\begin{array}{l}\text { Burundi, Congo and } \\
\text { Rwanda. }\end{array}$ \\
\hline $\begin{array}{l}\text { SADC } \\
\text { (excluding SACU) }\end{array}$ & $\begin{array}{l}\text { Cereals; milling } \\
\text { products; beverages; } \\
\text { miscellaneous edible } \\
\text { preparations; dairy } \\
\text { products; sugars and } \\
\text { edible vegetables. }\end{array}$ & $\begin{array}{l}\text { Zimbabwe; Angola; } \\
\text { Mozambique; Mauritius; } \\
\text { Zambia; Malawi; } \\
\text { Tanzania; Democratic } \\
\text { Republic of Congo and } \\
\text { Madagascar. }\end{array}$ & $\begin{array}{l}\text { Cotton; coffee, tea, } \\
\text { mate and spices; } \\
\text { tobacco; oil seeds; } \\
\text { food industry residue } \\
\text { and waste; fruits and } \\
\text { nuts and sugars. }\end{array}$ & $\begin{array}{l}\text { Zimbabwe; Zambia; } \\
\text { Malawi; Mozambique; } \\
\text { Tanzania; } \\
\text { Madagascar and } \\
\text { Mauritius. }\end{array}$ \\
\hline $\begin{array}{l}\text { COMESA } \\
\text { (excluding SACU) }\end{array}$ & $\begin{array}{l}\text { Sugars; cereals; } \\
\text { beverages; } \\
\text { miscellaneous edible } \\
\text { preparations; tobacco; } \\
\text { milling products; } \\
\text { prepared vegetables } \\
\text { and oil seeds. }\end{array}$ & $\begin{array}{l}\text { Zimbabwe; Angola; } \\
\text { Mauritius; Zambia; } \\
\text { Kenya; Malawi; } \\
\text { Democratic Republic of } \\
\text { Congo; Madagascar; } \\
\text { Egypt; Uganda; } \\
\text { Seychelles; Comoros; } \\
\text { Sudan; Ethiopia; Eritrea; } \\
\text { Rwanda; Libya; Djibouti } \\
\text { and Burundi }\end{array}$ & $\begin{array}{l}\text { Cotton; coffee, tea, } \\
\text { mate and spices; } \\
\text { tobacco; oil seeds; } \\
\text { food industry residue } \\
\text { and waste; fruits and } \\
\text { nuts; sugars and } \\
\text { prepared vegetables. }\end{array}$ & $\begin{array}{l}\text { Zimbabwe; Zambia; } \\
\text { Malawi; Kenya; } \\
\text { Egypt; Uganda; } \\
\text { Ethiopia; } \\
\text { Madagascar; } \\
\text { Burundi; Mauritius; } \\
\text { Comoros and } \\
\text { Rwanda. }\end{array}$ \\
\hline AMU & $\begin{array}{l}\text { Tobacco and edible } \\
\text { fruit and nuts. }\end{array}$ & $\begin{array}{l}\text { Algeria; Mauritania; } \\
\text { Morocco; Tunisia and } \\
\text { Libya. }\end{array}$ & $\begin{array}{l}\text { Dairy products; } \\
\text { miscellaneous edible } \\
\text { preparations and } \\
\text { fruits and nuts. }\end{array}$ & Morocco and Tunisia. \\
\hline
\end{tabular}

\section{Based on World Trade Atlas data}

10 Excluding SADC countries. If overlapping memberships are considered and exports to SADC countries are excluded, exports to COMESA only constitute $2 \%$ of global exports and $8.7 \%$ of African exports. If imports from SADC countries are excluded, imports from COMESA only constitute $0.57 \%$ of global imports and $7.3 \%$ of African import value. 


\section{CONSTRAINTS FOR GREATER INTRA-AFRICA TRADE.}

At an AGOA Forum hosted by the US in June 2005, the US Secretary of State stated that development in Africa can be fostered by African countries trading amongst themselves. However, there remain significant constraints limiting greater intra-African trade. These include both tariff and non-tariff barriers. This section outlines and discusses several of these barriers.

\section{Tariff barriers to trade}

Tariffs continue to be an impediment to greater intra-Africa trade. Table 5 indicates that each region applies a relatively high tariff rate for agricultural products. With reference to the existing trade patterns, it should be noted that as a signatory to the SADC trade protocol, South Africa enjoys preferential access to SADC economies, many of which are also COMESA members. This may explain the high level of exports to SADC and COMESA countries.

Table 5: Tariff barriers for agricultural products

\begin{tabular}{|l|l|l|}
\hline Economic community & MFN bound average & MFN applied average \\
\hline ECOWAS & 69.0 & 16.9 \\
\hline ECCAS & 66.7 & 20.1 \\
\hline SADC (excluding SACU) & 101. & 15.7 \\
\hline COMESA (excluding SACU) & 90.7 & 20.0 \\
\hline AMU & 69.4 & 17.6 \\
\hline SACU & 71.4 & 9.1 \\
\hline
\end{tabular}

\section{Source: World Trade Organisations trade database and ITC's Market Access database.}

In COMESA, ECOWAS, ECCAS and AMU member markets, South Africa faces each country's respective MFN tariff rates. ECCAS and COMESA have an average applied tariff of $20.1 \%$ and $20 \%$ respectively whilst ECOWAS and AMU's average applied tariff is $16.9 \%$ and $17.6 \%$ respectively. The role of these tariffs in determining trade flows is highlighted by the fact that, over a ten year period, the fastest growing regions for South African exports have been ECOWAS and the AMU, those regions with the lowest average applied tariffs (table 3 ).

Relative to other African regions, SACU's average applied tariff is low at $9.1 \%$. Preferential market access for SADC countries may explain why most imports from Africa come from the SADC region. The trade data indicates that imports from other African countries continue to lag behind imports from the rest of the world despite a relatively low tariff (table 3). Tariff barriers in the South African market do not therefore appear to be a significant explanation for the low level of imports from other African countries. The next section examines some of the other possible explanations for this continued low level of imports from African partners.

\section{Other Barriers to Trade}

In a trade context, tariff barriers do not act as the only market access constraint. A number of other factors impact market access and hence trade flows. These factors are particularly important in an African context. The United Nations Economic Commission for Africa (ECA, 2005) divides market access constraints into three broad categories, namely: natural barriers, man-made barriers and non-tariff or technical barriers. Natural barriers to trade refer to supply side and production constraints, including social and political conflict and infrastructure constraints. Man-made constraints and non tariff barriers refer to: import and export restrictions; customs formalities; export procedures such as custom valuation; SPS (sanitary and phytosanitary measures); and technical barriers such as technical regulations and standards that set out specific characteristics of a product such as its size, shape, design or labelling or packaging of the product. 
An important contributor to low intra-Africa trade, both on the export and import side are natural barriers to trade. Natural barriers to trade are often referred to as supply-side constraints. Supply-side constraints are the kind of barriers that are related to production capacity, diversification potential and the range of products exported by a country. Constraints on supply in an agricultural context can range from political conditions, climatic conditions and land size, to available technology and human resources. The increased importance of value addition in South African agriculture requires increased imports of intermediate products and not just primary commodities. African countries that do not diversify their production and export profiles limit their potential to the supply of one or two commodities. The continued reliance on exports of a few primary commodities represents one of the main reasons for the low growth in exports to the South African market and low levels of intra-Africa trade on the import side, as the trade profile in tables 3 and 4 indicate. In addition, as incomes rise in African countries, consumers demand greater choice in the variety of products and increasingly sophisticated products. In the absence of capacity for local production, increased demand for imports of such products provides an opportunity for South African exporters of processed and high value products to take advantage of opportunities in such markets. This will only serve to perpetuate current trade imbalances as South Africa continues to increase exports to African countries.

The nature of a country or region's infrastructure has an important impact on its trade performance and competitiveness. Geographic proximity to markets, partner countries and ports are particularly important in this regard. In this respect the distinctness of Africa with respect to climate and location is also important. The fact that much of Africa is semi-arid with low population densities and a large number of landlocked countries, results in intrinsically high transport costs (Collier \& Gunning, 1999). This is compounded by policy-induced deficiencies in infrastructure. Transport related trade costs, infrastructure-induced increases in trade costs and additional trade costs induced by inefficient and/or excessive bureaucracy, all act to limit trade by raising the transaction costs of conducting business. ECA (2004:107) suggests that greater intra-African trade is hampered by inadequate infrastructure that acts as a major source of comparative disadvantage. High transaction costs related to infrastructure impede greater trade.

Transport infrastructure is particularly critical to trade as it facilitates the movement of goods between points of production to final destinations. High transport costs can price a country out of the export market. Limoa and Venables (2000) have shown that 10\% increase in transport costs results in reduction in trade volumes by approximately $20 \%$. ECA (2005) argues that transport costs that are a high proportion of the value of exports add to the high cost of import goods and thus reduce their competitiveness in foreign markets. Therefore, high transport costs will serve as a barrier to trade amongst African countries. High transport costs are caused by inadequate infrastructure networks and inefficient transport operations (ECA, 2005). Figure 1 shows transport costs in different regions in the world and country groupings.

Transport cost is calculated as a ratio of transport costs incurred in export of a product as a percentage of import value. Africa has the highest transport costs compared to other regions in the world. Transport costs in Africa are estimated at $13 \%$ while industrialised countries have transport costs of $5.5 \%$. The impact of this on trade is that the burden of high transport costs is often shifted onto freight customers, raising the costs of goods and negatively affecting competitiveness.

Internal transport costs are often a more serious source of competitive disadvantage than inter-country export costs (UNCTAD, 1999). The lack of infrastructure for getting exports from production areas through ports and out of the country remains a serious impediment to greater intra-Africa trade. Figure 2 shows road network distribution and density in Africa. West and North Africa have low road network distribution while Southern Africa has a higher level of road network distribution. Examining this distribution with reference to South Africa's trade profile, it appears that transport, and in particular road infrastructure, is an important determinant in South Africa's trading relationship with the rest of Africa. The regions with the highest levels of road distribution are the same regions with which South Africa records the highest level of imports and exports, Southern Africa (SADC) and East Africa (COMESA). 
Figure 1: Transport costs by world regions (\%), $2000^{11}$

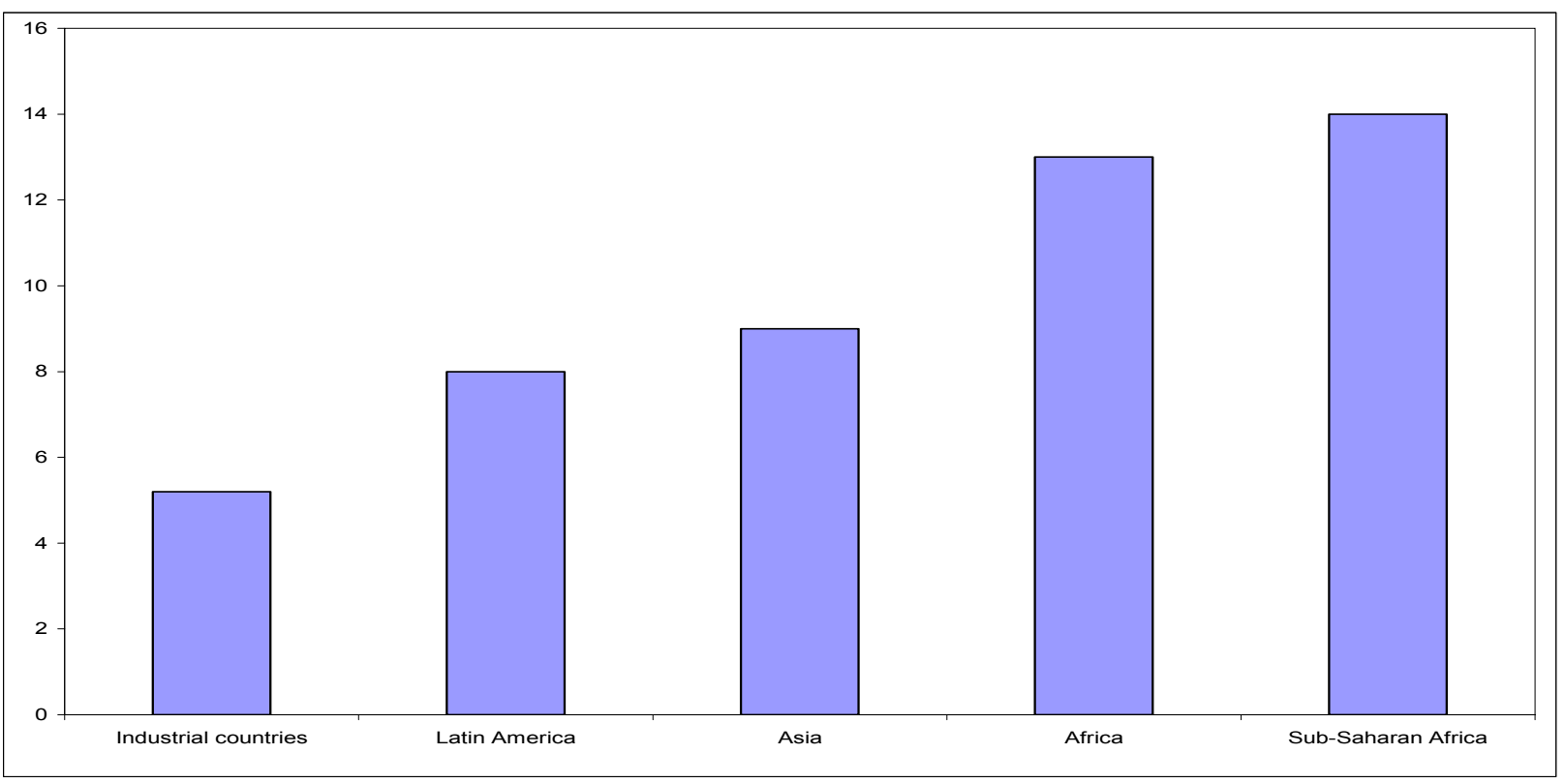

Source: ECA (2004)

Figure 2: Road network distribution and density across Africa

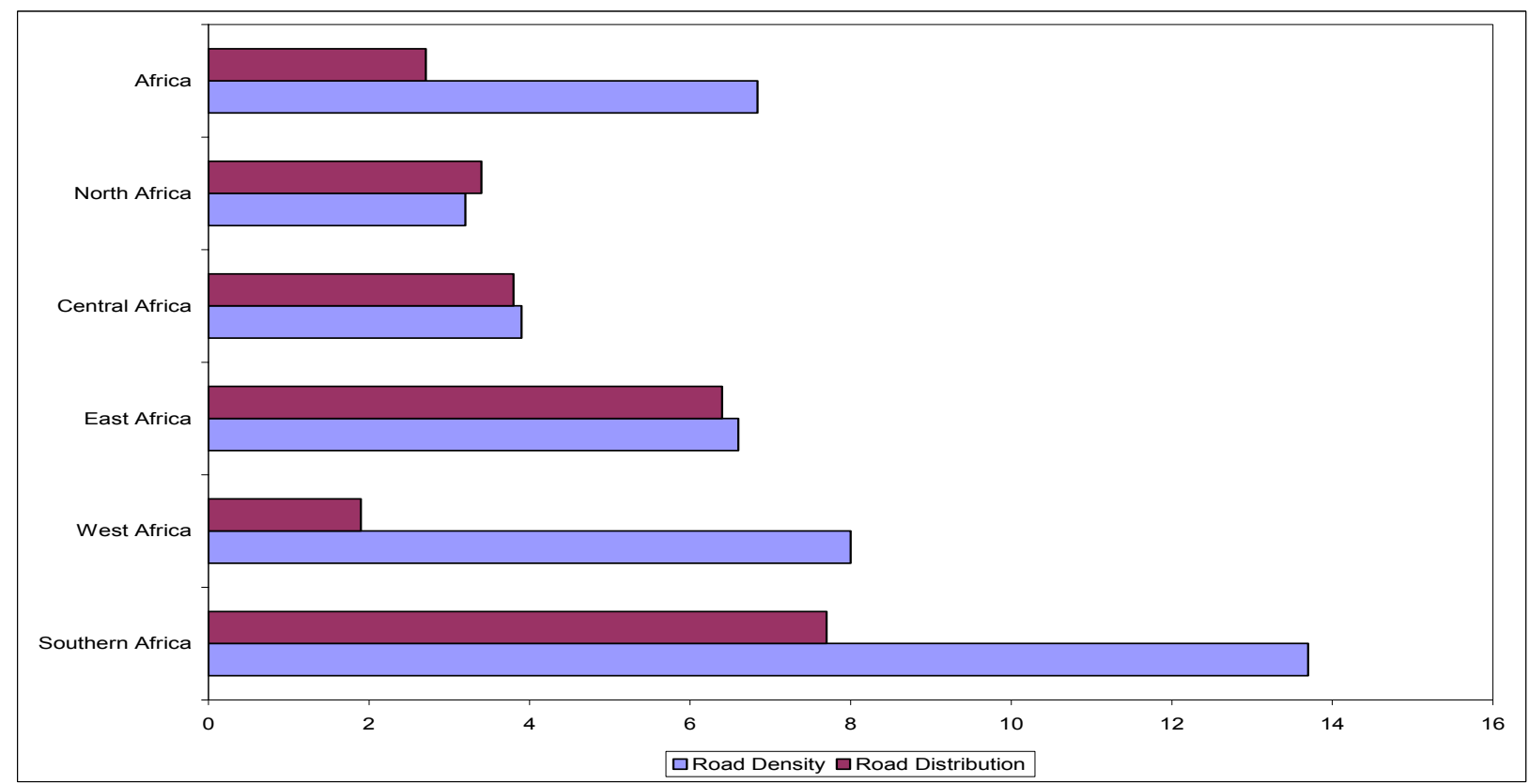

Note: Network density is in $\mathrm{km}$ per $100 \mathrm{sq} \mathrm{km}$. Distribution is in $\mathrm{km}$ per 10,000 inhabitants.

Source: ECA (2005:160).

\footnotetext{
${ }^{11}$ Transport cost rate is the ratio of transport costs as a percentage of value of imports.
} 
In addition to transport infrastructure, efficient and cost effective energy and telecommunications infrastructure is also essential for businesses wishing to compete globally. Poor energy and telecommunications infrastructure further restricts the potential for greater intra-Africa trade. The inability to provide adequate and cost effective energy services limits the production possibilities of an economy and constrains attempts at diversification. Unreliable and expensive energy across most African economies increases business costs, as organisations need to invest in generators, which raises energy costs and results in the marginalisation of small enterprises that cannot afford high costs. These factors all contribute to deterring potential investment in sectors that may possess a comparative advantage. Inadequate supply of and the low use of telecommunications technology, is a further inhibitor to greater intra-African trade. Businesses, without access to quality and affordable telecommunications, remain unaware of up-to-date information in their respective industries including market trends and prices, thus further isolating them from potential markets.

The quality of countries' institutions is also important in the context of trade. Rodrik (2004) argues that institution quality needs to be tied to context or country-specific needs and objectives. However, the author acknowledges that there is widespread acceptance that respect for the rule of law, clearly defined property rights, a strong judicial system, and clear, consistent and predictable monetary and fiscal policies grounded in macro economic institutions, are essential in promoting growth and attracting investment. In an African context where nurturing of the small-scale agricultural sector that is often responsible for a large proportion of total production and trade is vital, the role of countries' institutions in attracting investment is particularly important. Limited and, in some instances, no access to capital markets restrict the potential for small-scale producers to upgrade their production to export scale and quality. This problem is compounded by insecure land tenure arrangements that do not allow farmers or producers access to finance for investing in their production systems. Private sector investment has the potential to provide the necessary capital for investing in developing small-scale producers, allowing them to diversify their production and become internationally competitive. Institutions that foster an investor-friendly climate are needed to ensure that investment is attracted to industries where comparative advantage exists or competitive advantage could be created.

Corruption in African economies is often cited as a major deterrent to potential investors and traders. Countries with corrupt administrations and weak judiciaries will find it difficult to attract capital for investing in production and exports. Corruption and the perception of corruption are important impediments to trade as they increase both the risk and cost of conducting business in a country. Table 6 provides an indication of the corruption perception across various regions.

Table 6: Corruptions perception index 2005

\begin{tabular}{|l|l|}
\hline Region & Average CPI score \\
\hline World Average & 4.11 \\
\hline Africa Average & 2.86 \\
\hline ECOWAS $^{12}$ & 2.67 \\
\hline ECCAS $^{13}$ & 2.28 \\
\hline SADC $_{\text {(excluding SACU) }}$ & 2.76 \\
\hline COMESA $^{14}$ (excluding SACU) & 2.70 \\
\hline AMU & 3.35 \\
\hline SACU & 4.16 \\
\hline
\end{tabular}

Source: Based on Transparency International's Corruption Perception Index 2005.

\footnotetext{
${ }^{12}$ No data for Cape Verde; Guinea; Guinea-Bissau and Togo.

${ }^{13}$ No data for Central African Republic and Sao Tome and Principe.

${ }^{14}$ No data for Comoros and Djibouti.
} 
Table 6 uses data from Transparency International and the rankings are based on a scale of 0 to 10 , where ' 10 ' is highly clean and ' 0 ' is highly corrupt. As the table indicates, the perception of corruption in Africa across all the regional economies is high. All African regions, except SACU, rank well below the global average implying that those African countries are perceived as being more corrupt than most other countries in the world. The quality and strength of effective institutions is essential in overcoming these perceptions and promoting greater trade. Examining this index with reference to South Africa's trade profile, it appears that the regions with the lowest average growth in terms of exports to South Africa, ECOWAS and ECCAS are also the regions perceived to be the most corrupt on the continent.

In order to improve the continent's ability to trade, other persistent constraints also need to be addressed. Man-made barriers to trade relating to customs and payment procedures also contribute to the cost of goods and consequently impact on competitiveness. The lack of transparency and predictability of customs barriers across many African countries is a significant barrier to trade (ECA, 2004). While studying the trade potential between South Africa and Nigeria, Daya and Steenkamp (2005) found that Nigerian authorities control imports by using a variety of trade policy instruments including import restrictions. It was found that the details on prohibited imports are not always readily available and are not easily obtainable creating a negative perception amongst potential exporters. These problems are exacerbated by continued customs inefficiencies resulting from inadequate infrastructure, resources and technology that result in delays and increased costs of doing business. ECA (2005:169) cites UNCTAD estimates that suggest an average customs transaction in Africa involves 20-30 different parties, 40 documents, 200 data elements and the re-keying of all data at least once. Delays and cumbersome customs formalities in turn contribute to greater transport and inventory charges, further eroding competitiveness. These hindrances constrain trade growth and act as a disincentive to private investment, which is essential in ensuring that African producers are able to diversify production and compete in the South African market.

Adapting your product to the needs of consumers and ensuring an acceptable level of quality is also critical in being a successful exporter of products. This is particularly relevant in the agricultural sector where health, environmental considerations, and traceability are becoming increasingly critical factors for consumers. This is reflected in the fact that technical (TBT) and sanitary and phytosanitary requirements (SPS) have become an increasingly important means of regulating imports. These regulations may relate to consumer safety, health requirements, protecting the environment or other quality characteristics. Meeting such requirements imposes higher production costs on producers and limits the potential for poorer countries to access the markets of more advanced countries. In an African context, the South African market can be considered an advanced market and standards become an important requirement in trade. African exporters wishing to access the South African market are often confronted with stringent SPS and TBT barriers. This is a result of the relatively well-developed standards and monitoring authorities and institutions in the country. It also reflects the relatively high per capita income of consumers who increasingly place emphasis on issues like quality, health considerations and traceability. African economies need to develop internationally recognised monitoring, testing and certification authorities to ensure compliance with SPS requirements. In the absence of harmonised agreements and/or adequate investment in upgrading African facilities, this will persist as an obstacle to other African countries accessing the South African market.

\section{ECONOMIC IMPACT}

Further strengthening of regional integration initiatives needs to be pursued thus allowing more countries preferential access to other African markets including the South African market. However, agricultural trade needs to be fully incorporated into such arrangements given the large share agriculture covers in the trade of many regions. In addition to tariff reductions, revenue duties, informal restrictions to trade, and extensive parastatal control over export commodities all need to be addressed to ensure freer agricultural trade on the continent (IPC, 1998:5). Regional integration also provides benefits in terms of economies of scale and the creation of huge internal markets that facilitates competition and efficient production. Deeper integration could also enable Africa to increase investment in capital goods allowing for further 
processing of raw materials within the region before exporting. In this way, production is diversified and African producers can move up the value chain. An initial step may be to promote the production of semiprocessed products for export. However, preferential access may afford beneficiary countries a competitive advantage but it does guarantee an increase in trade. Integration efforts need to address issues of infrastructure, trade finance, marketing, training and other factors for production or countries' risk remaining in a position of either not being able to supply or not being able to supply competitively (Manduna, 2005). A coordinated regional and continental wide approach to infrastructure financing, institutional harmonisation and policy coordination needs to be pursued to ensure that the benefits and opportunities accruing form preferential access are optimised. This can be achieved within the overarching framework of the NEPAD initiative.

Addressing the challenges to trade in Africa requires a comprehensive approach that focuses on a range of issues that supplement preferential access arrangements and facilitate greater competitiveness of African economies. Investment in upgrading infrastructure, developing human capital and transferring technologies and expertise, are critical in ensuring diversification of production and greater opportunities for trade. Improving the transport infrastructure on the continent is critical to enhancing trade. UNCTAD (1999) suggests that the transport sector is critical in creating a dynamic investment-export nexus in Africa. This is particularly important in an agricultural trade context where transport costs constitute a large component of the final cost of goods. In addition, UNCTAD (1999:6) argue that, because shipping tariffs are set according to the strength and weakness of demand rather than costs of carriage per se, the processing and thus diversification of natural resources prior to exporting is constrained by the tendency for ad valorem transport rates to increase with additional fabrication. Broader infrastructural development and investment in the energy and telecommunications sectors is also needed. Public investment and development assistance targeting infrastructure development and maintenance is essential in the absence of domestic and foreign private investment and may also act to stimulate private investment. Trade facilitation in the form of less cumbersome and harmonised customs procedures, upgrading and automating port facilities and training, all have the potential for creating a trade-enabling environment thus promoting greater intra-Africa trade.

South Africa's developed commercial farming sector along with marketing and processing abilities, places the country in a unique position in Africa in terms of human capital and expertise. These resources provide a valuable opportunity for South African farmers, producers, processors and managers to export their skills to African economies. Management, marketing and business skills and experience could contribute significantly to advancing African agricultural development initiatives whilst at the same time establishing and cementing bilateral relations that may further reinforce trade. The export of South African skills and technologies and investment in African agriculture and infrastructure can contribute significantly to the revolution of African agricultural production. This may, in turn, serve to reduce trade imbalances as African economies promote trade based on created competitive advantages and not merely dependant comparative advantages. This would also be consistent with the objectives espoused by the African Union and in NEPAD and the CAADP.

\section{CONCLUSION}

South Africa is the most active African participant in agricultural trade on the continent. This is largely driven by exports to other African countries. South Africa continues to enjoy large imbalances in trade with all the economic communities across Africa and exports to Africa are almost six times larger than imports from the continent. The limited range of potentially importable commodities from the rest of Africa is in stark contrast to the diversified range of exports available from South Africa. In the absence of efforts on the part of African economies to develop their agricultural sectors and diversify production out of primary commodities, this trend of huge trade imbalances will persist. Reducing these imbalances requires significant and coordinated investments in increasing the productive potential and competitiveness of African countries thereby allowing them to link in the value chain. Preferential market access through regional agreements needs to be strengthened and complimented with investments in education, infrastructure and technology. The success of these arrangements in terms of trade flows is evident from 
the important role SADC has come to occupy in South African agricultural trade. This has been fostered through preferential access as well as substantial investment in infrastructure, most notable being the transport corridors. Although the challenges to promoting greater intra-Africa trade remain significant, they are not insurmountable. A determined and coordinated effort aimed at investing in productive industries and allocating resources efficiently, developing quality infrastructure and fostering a trade and investment enabling environment, are critical if greater trade is to be realised.

\section{REFERENCES}

AU. 1991. Abuja Treaty: Treaty establishing the African economic community, African Union [Online] Available from: www.africa-union.org [Accessed: 28/06/2006].

Collier P \& Gunning JW. 1999. Explaining African economic performance. Journal of Economic Literature, 38: 64-111.

Daya Y \& Steenkamp E. 2005. Trade potential between South Africa and Nigeria, Working paper, Department of Agriculture, Pretoria, South Africa [Online] Available from: www.nda.agric.za [Accessed: 28/06/2006].

DoA. 2001. South Africa's Agricultural Trade Strategy, internal document, Department of Agriculture. Pretoria, South Africa.

FAO. 2004. Trade in forest products in Africa: opportunities and challenges, presented at the Workshop on strengthening regional action - implementation of the IPF/IFF proposals for action in Africa, Food and Agriculture Organization of the United Nations, Accra, Ghana, 16-18 February 2004.

IPC. 1998. The role of regionalism in agricultural trade reform, International Policy Council on Agriculture, Food and Trade, Washington.

ITC. 2001. Foreign trade statistics: a guide for their use in market research, International Trade Centre, Market Analysis Section, Geneva.

Kousari K. 2004. Trade performance and commodity dependence, paper presented at FAO regional conference trade and development workshop, Johannesburg [Online] Available from: www.nda.agric.za viewed [Accessed: 28/06/2006].

Limao N \& Venables A. 2000. Infrastructure, geographical disadvantage and transport costs. Washington: World Bank.

Manduna C. 2005. Assessing the causes of sub Saharan Africa's declining exports and addressing supply side constraints, TRALAC working paper, No. 2, May 2005 [Online] Available from: www.tralac.org.za [Accessed: 09/08/2006].

NEPAD. 2000. Common African Agricultural Development Programme, New Partnership for African Development [Online] Available from: www.nepad.org [Accessed: 28/06/2006].

Rodrik D. 2004. Getting institutions right, Harvard University [Online] Available from: http://ksghome.harvard.edu/ drodrik/papers.html [Accessed: 09/08/2006].

South Centre. 1996. International commodity problems and policies: key issues for developing countries, South centre, Geneva [Online] Available from: www.southcentre.org [Accessed: 28/06/2006].

UNCTAD. 1999. African transport infrastructure, trade and competitiveness, United Nations Conference on Trade and Development, TD/B/46/10, Geneva [Online] Available from:

http://www.unctad.org/en/docs//tb46d10.pdf [Accessed: 09/08/2006]. 
UNCTAD. 2003. Economic development in Africa, trade performance and commodity dependence, United Nations Conference on Trade and Development, Geneva [Online] Available from: www.unctad.org [Accessed: 28/06/2006].

UNECA. 2004. Economic report on Africa for 2004: Unlocking Africa's trade potential, United Nations Economic Commission for Africa, Addis Ababa [Online] Available from: www.uneca.org [Accessed: 28/06/2006].

UNECA. 2005. Trade facilitation to promote intra-Africa trade, Committee on Regional Cooperation and Integration, Fourth Session, United Nations Economic Commission for Africa, Addis Ababa, Ethiopia, 2425 March 2005.

World Bank. 2003. Africa Region Trade Progress Note, Washington, D.C. 